\title{
Frontoethmoidal meningoencephalocele: a common and severe congenital abnormality in South East Asia
}

\author{
Christopher G M Richards
}

\begin{abstract}
The clinical features of 23 cases of frontoethmoidal meningoencephalocele are described in two South East Asian populations. The clinical, embryological, and epidemiological evidence may support an early teratogenic insult in the aetiology of this congenital defect.
\end{abstract}

Frontoethmoidal meningoencephalocele (FEM) is a congenital abnormality involving the herniation of meninges and cerebral tissue through a defect in the anterior cranium, between the frontal and ethmoidal bones. Although rare in Europe and the USA, the condition has been described previously in a number of racial groups in South East Asia, including Thais, Malaysians, and Burmese.

This study describes the clinical features of FEM in two ethnic groups. The Cambodian cases were detected at presentation in an outpatient facility of a refugee camp and the Thai cases were identified in an orphanage in Bangkok.

\section{Methods and results}

CAMBODIAN CASES

Seven children with FEM were seen at an outpatient facility serving a refugee camp on the Thai-Cambodian border (table and figure). Their ages ranged from newborn to 4 years with a sex distribution of five girls to two boys. All cases were diagnosed clinically.

The children presented with a progressively enlarging nasal or paranasal subcutaneous mass of which four were firm and three were fluctuant and of the latter, two were reducible. In three cases palpation of the mass caused irritation to the child, as though it was sensitive but not painful. No mass transilluminated. In two cases there was a transmitted pulsation but in neither case was there a thrill or murmur. In three cases the mass was covered by scar-like tissue which had been present since birth, and in a fourth by hyperpigmented skin containing some dark

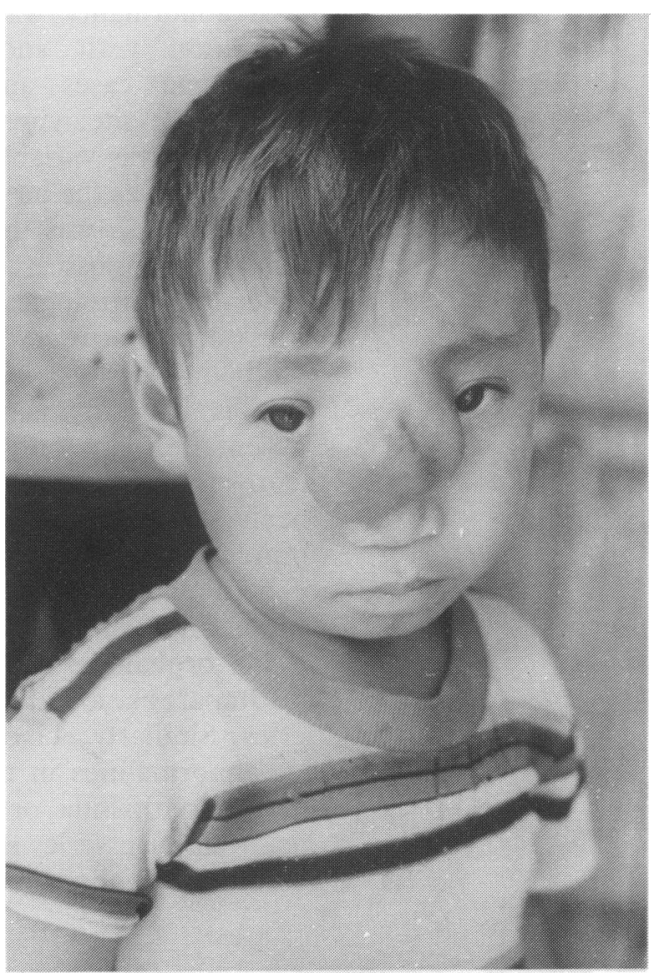

Frontal view of 4 year old boy with a large nasal mass covered by scarring and a divergent squint.
Thai-Cambodian border Correspondence to: Dr C G M Richards, Department of Paediatrics, John Radcliffe Hospital, Headington, Oxford OX3 9DU.

Accepted 8 January 1992
Abnormalities associated with FEM in a Cambodian refugee camp and a Bangkok orphanage in comparison with other series

\begin{tabular}{|c|c|c|c|c|c|}
\hline & $\begin{array}{l}\text { Cambodian } \\
\text { cases } \\
(\boldsymbol{n}=7)\end{array}$ & $\begin{array}{l}\text { Bangkok } \\
\text { orphanage } \\
(n=16)\end{array}$ & $\begin{array}{l}\text { Neurosurgical } \\
\text { referrals to } \\
\text { Australia' } \\
(n=25)\end{array}$ & $\begin{array}{l}\text { Neurosurgical } \\
\text { referrals in } \\
\text { Bangkok }(1966)^{2} \\
(n=25)\end{array}$ & $\begin{array}{l}\text { Neurosurgical } \\
\text { referrals in } \\
\text { Bangkok }\left(1971^{*}\right)^{3} \\
(n=100)\end{array}$ \\
\hline $\begin{array}{l}\text { Nasal mass } \\
\text { Microphthalmia } \\
\text { Anophthalmia } \\
\text { Bilateral anophthalmia } \\
\text { Corneal clouding } \\
\text { Cutaneous scar } \\
\text { Hydrocephalus } \\
\text { Microcephalus } \\
\text { Cerebral palsy } \\
\text { Female:male } \\
\text { Racial origin }\end{array}$ & $\begin{array}{l}7 \\
2 \\
1 \\
0 \\
2 \\
3 \\
0 \\
0 \\
0 \\
5: 2 \\
\text { Cambodian }\end{array}$ & $\begin{array}{l}13 \\
5 \\
3 \\
1 \\
7 \\
13 \\
8 \\
3 \\
7 \\
4: 12 \\
\text { Probably Thai }\end{array}$ & $\begin{array}{l}25 \\
0 \\
0 \\
0 \\
\text { Not discussed } \\
\text { Not discussed } \\
6 \\
\text { Not discussed } \\
\text { Not discussed } \\
12: 13 \\
\text { Malay }(n=18) \text {, } \\
\text { Indian }(n=2) \text {, } \\
\text { Australian } \\
\text { aborigine }(n=3) \text {, } \\
\text { Papuan }(n=1), \\
\text { European }(n=1)\end{array}$ & $\begin{array}{l}25 \\
4 \\
0 \\
0 \\
\text { Not discussed } \\
\text { Not discussed } \\
3 \\
5 \\
\text { Not discussed } \\
11: 14 \\
\text { Probably Thai }\end{array}$ & $\begin{array}{l}100 \\
7 \\
1 \\
0 \\
\text { Not discussed } \\
\text { Not discussed } \\
10 \\
7 \\
\text { Not discussed } \\
\text { Not discussed } \\
\text { Probably Thai }\end{array}$ \\
\hline
\end{tabular}

*1971 series probably includes cases from the 1966 series. 
coarse hairs. One case had a left cleft lip and palate, bilateral club feet, and an anterior anal opening in addition to the paranasal mass. Four cases had associated microphthalmia and/or anophthalmia. Two cases had partial corneal clouding. A skull radiograph revealed a frontoethmoidal bony defect in all four cases in which it was performed.

\section{BANGKOK ORPHANAGE CASES}

This institution cares for 400 handicapped children under 9 years of age. Sixteen cases of FEM were diagnosed clinically (see table). All children identified were thought to be of Thai racial origin. Their ages ranged from $2 \cdot 4$ to 9 years with a sex distribution of four girls to 12 boys.

All had some distortion of nasal or paranasal skin and soft tissue. In two cases there was no mass but only a distorted nasal root covered by scar-like tissue, and in a single case the only nasal abnormality was the scar-like tissue in association with anophthalmia. As in the Cambodian cases and in previous clinical studies, the site, consistency, and size of the nasal mass was variable. Most were firm. Only in one case was the mass fluctuant and reducible and in no case was the mass pulsatile, transilluminable, or possessed a thrill or murmur. The associated neurological abnormalities in these cases are more severe than in the above Cambodian cases or previous series (see table). This is not surprising as case detection by presentation in outpatient departments, to neurosurgical centres, or by postal inquiry inevitably selects milder cases than would be found among children institutionalised because of mental and physical handicap. It is noteworthy, for example, that seven of the 16 cases in the orphanage were found to have spastic quadraparesis, a feature not described in other series. Similarly, 11 of the 16 cases had gross eye abnormalities in the form of microphthalmia, anophthalmia, or corneal clouding whereas in a Malaysian series none of the 25 had a gross structural eye abnormality.

\section{Discussion}

\section{EPIDEMIOLOGY}

The incidence of FEM is closely related to geographical location. A birth survey in Bangkok reported an incidence of one in $6000 .^{4}$ Prevalences of similar value were noted in a community survey in rural Thailand ${ }^{4}$ and by postal inquiry in rural and urban Burma. ${ }^{5}$ In contrast the condition is not described in several large birth surveys in the USA. ${ }^{6}$ It is not known if these racial groups retain their high prevalence upon migration to temperate areas. The incidence of FEM seems to be independent of spina bifida within a defined population, providing no justification for naming the condition 'cranium bifidum' as it was originally known. If frontoethmoidal, occipital or spinal meningomyeloceles were related defects representing part of an embryonic progression then their incidences would be expected to vary directly or inversely. Neither is the case. Accordingly, the ratio of cranial to spinal meningomyeloceles treated in neurosurgical units contrasts between 1:5.2-7.4 in American studies and 3.5:1 in Thailand, ${ }^{4}$ but spina bifida is not unduly rare in Thailand with an incidence of approximately one in 8500 live hospital births.

Two other interesting observations were made by Aung Thu and Hta Kyu in the Burmese study. ${ }^{5}$ Conception of subjects with FEM was significantly rarer in the cold season than in rural controls, both in those attending neurosurgical centres and found by postal inquiry. They also found that the parents of cases were more often unemployed or working as rice farmers and less likely to be craftsmen or production workers than in the general population. It is not clear, however, to what extent this finding is affected by a bias of postal respondents.

In the Cambodian cases and in all but one other study, relatives of FEM cases have been unaffected. The exception was in a study by Flatz and Sukthomya who described four of 13 cases in northern Thailand who had a close relative with the condition. ${ }^{7}$ In this study, however, information was not given about the incidence of interfamily marriages in the area or the geographical distribution of the affected cases. The lack of familial cases in most studies suggests that mendelian dominant or recessive inheritance is unlikely, although polygenic inheritance is possible.

\section{PATHOLOGY AND EMBRYOLOGY}

Postmortem studies and observations at surgical exploration show the opening in the cranium to be located between frontal and ethmoidal bones, anterior to the crista galli and cribriform plate at the site of the foramen caecum. ${ }^{13}$ In one of these studies the opening was single in the midline in $40 / 72$, bilateral on either side of the midline in $20 / 72$, and unilateral in $12 / 72 .^{3}$ The herniation extrudes through the skull in various directions and locations around the site of meeting of the nasal, maxillary, and lacrimal bones. This variation together with extent of herniation explains the variety of clinical appearances. The herniation contained at least the frontal tips in 70/72 cases together with a variable quantity of brain tissue. ${ }^{3}$ None of the 25 cases described by David et al showed involvement of the ventricular system in the herniation. ${ }^{1}$ In this series, viable brain tissue was usually present at the neck of the hernia but more distal biopsy specimens showed only glial tissue.

There are a number of possible embryological explanations for the associated abnormalities in cases of FEM. Direct pressure by the hernia on orbital structures may explain the origin of anophthalmia or microphthalmia in some cases, but not in those in whom the eye abnormality occurs contralaterally to the side of prominent herniation. Although in severe cases massive herniation displaces the brain forward distorting the optic nerves, ${ }^{3}$ which could lead to atrophy of intraorbital structures in utero, this cannot always be the alternative explanation as eye abnormalities are common in clinically mild cases. Except in cases of massive herniation 
where occlusion of the foramen of Monroe has been described, it remains to be explained why so many cases develop hydrocephalus. The presence of nasal scar-like tissue is also a striking feature of this condition that has yet to be explained. This might be caused by in utero exposure of unepithelialised herniation with later epithelialisation to form this curious area of defective skin.

The simplest explanation is that the various abnormalities originate from a defect in cell development or migration at the stage of the three week embryo when eye and neural fields lie in close proximity. FEM have been found associated with holotelencephaly, ${ }^{2}$ supporting the idea that the defective step is early in development. The three week embryo predates formation of cartilage or ossification centres and therefore it may be that, unlike most other types of hernia, the contents, not the defect in the wall, is the primary abnormality. The presence of anterior and posterior fontanelles throughout fetal life provides evidence that the normally developing brain does not breech a meningeal covered break in the cranial vault.

\section{AETIOLOGY - A HYPOTHESIS}

Some of the epidemiological and pathological evidence supports the idea that a FEM is a consequence of a teratogenic insult. Favoured candidates proposed by Aung Thu and Hta Kya are the aflatoxins, produced by one genus of the imperfect fungi, aspergillus. ${ }^{5}$ These toxins have been found in food samples taken from markets in Thailand and in the secretions and tissues of well and sick Thai children. ${ }^{8}$ One of the aflatoxins, ochratoxin $\mathrm{A}$, has been shown to induce a range of gross abnormalities-including exencephaly, anophthalmia and cleft lip-in mouse fetuses after a single intraperitoneal injection of the pregnant adult on day 7-12.9 Such toxins may be present in the diet in higher concentrations during the hot, humid months and when foodstuffs are stored for long periods in poorly ventilated rooms. This hypothesis is consistent with the bias away from cold season conception among cases of FEM and the higher incidence among the children of poor rice farmers and the unemployed reported in the Burmese study. ${ }^{5}$

The hypothesis could be tested in a number of ways. The incidence of the condition at birth could be recorded in a defined population before and after elimination of the aflatoxins from the diet. However, one alarming feature of these toxins is that they are not eliminated by cooking. ${ }^{10}$ Treatment of food with ammonia, sodium hypochlorite, or hydrogen peroxide may provide a more effective means of removing the toxin. ${ }^{11}$ Another approach would be to use a mammalian model to study the effects of the specific type of aflatoxin that might be found in the blood of pregnant women living in areas where FEM is common, although the possible species specific nature of the toxin's teratogenic effect may make these observations hard to interpret.

I am grateful to Janet Taylor in helping to collect clinical informatin on the Cambodian cases.

1 David DJ, Sheffield L, White J. Fronto-ethmoidal meningoencephalocoele. Fournal of Plastic Surgery 1984;37:271-84. 2 Suwanwela C, Hongsaprabhas C. Fronto-ethmoidal encephalomeningocoele. $\mathcal{J}$ Neurosurg 1966;25:172-82.

3 Suwanwela C, Sukabote C, Suwanwela N. Fronto-ethmoidal encephalomeningocoele. Surgery 1971;69:617-25.

4 Suwanwela C. Geographical distribution of frontoethmoidal encephalomeningocoele. British fournal of Preventive and Social Medicine 1972;26:193-8.

5 Thu A, Kyu H. Epidemiology of fronto-ethmoidal encephalomeningocoele in Burma. $\mathcal{F}$ Epidemiol Community Health 1984;38:89-98.

6 Harris LE, Steinberg AG. Abnormalities observed during the first six days of life in 8,716 live-born infants. Pediatrics 1954;14:314.

7 Flatz G, Sukthomya C. Fronto-ethmoidal encephalomeningocoele in the population of northern Thailand. Humangenetik 1970;11:1-8.

8 Bourgeois C, Olson L, Comer D, et al. Encephalopathy and fatty degeneration of the viscera. Am $\mathcal{F}$ Clin Pathol 1971;56: 558-71.

9 Hayes AW, Hood RD, Lee HL. Teratogenic effects of ochratoxin in mice. Teratology 1973;9:93-8.

10 Stoloff L, Trucksess MW. The effect of boiling, frying and baking on the recovery of aflatoxin from maturally contaminated corn grits or corn meal. 7 Assoc Off Anal Chem 1981;64:678-80.

11 De Vries HR. Aflatoxins and child health in Kenya. Rotterdam: Erasmus University, 1989. (MD thesis.) 